\title{
Competing norms of standard pronunciation. Phonetic analyses on the <-ig)-variation in Austria
}

\author{
Manuela Lanwermeyer, Johanna Fanta-Jende, \\ Alexandra N. Lenz, and Katharina Korecky-Kröll
}

\begin{abstract}
This paper focuses on phonetic variation within the standard German language register of Austria. While the norm status and a high socio-symbolic value are attributed to certain lexical variants of standard language in Austria, the norm and usage status of characteristic phonetic properties remain unclear, due to lack of empirical analyses. By investigating the relation between standard language norms and "standard usage" (Gebrauchsstandard) in Austria, our study aims to close this research gap by using the example of unstressed 〈-ig〉. The analyses are based on data gathered from 52 speakers from two generations, covering all Austrian dialect regions. Elicitation settings varied from strongly standardized tasks with a graphic or visual stimulus (reading aloud tasks, picture naming tasks) to translation tasks (translation from dialect into standard) with oral stimuli. The results demonstrate that although $\langle$-ig $\rangle$ is predominantly pronounced like [Ik], (socio-)linguistic factors as phonetic context, part of speech, setting, gender and regional background influence the $\langle$-ig $\rangle$-variation. In total, the data suggest that German speaking Austrians are situated in a conflict between transnationally diverging norms and intra-nationally varying model speakers of German.
\end{abstract}

\section{Keywords}

standard language, phonetic variation, German in Austria, language norm, pluricentricity

\section{Introduction}

This paper focuses on the phonetic variation within the standard German language register. German is often described as a "pluricentric" language with "several interacting centres, each providing a national [standard] variety with at least some of its own (codified) norms" (Clyne 1992: 1; see Herrgen 2015, Scheuringer 1996, Glauninger 2013 for a critical discussion). While Germany is hierarchically classified as "dominant centre" (see Clyne 1995: 22, Auer 2013, section 2), this paper discusses the variation of the standard language spoken in Austria - a "non-dominant centre" when viewed from a pluricentric perspective. This asymmetry between the 'centres' of the German-speaking areas is both 
traceable structurally and reflected in speakers' attitudes (see Schmidlin 2011, Ammon et al. 2016).

While norm status and high socio-symbolic value are attributed to certain lexical variants of the standard (or standard-related) language in Austria, the norm and usage status of characteristic phonetic properties of a/the Austrian standard language remain unclear. This is largely because empirical analyses concerning the function and use of these phonetic features are sparse or missing entirely. Furthermore, codices of standard German language pronunciation - pointing out overt pronunciation norms - usually focus on the pronunciation of the standard register(s) spoken in Germany. In contrast, similar national-scale pronunciation norms are rare for Austria (see section 3.1 for more details). By investigating the relation between standard language norms on the one hand and "standard usage" (Gebrauchsstandard) on the other hand, our analyses aim to close this research gap. "Standard usage" can be defined as a form of speech, used by highly educated speakers in formal speech settings (see Kleiner 2014: 277). To illustrate this, we will investigate the articulation of unstressed «-ig) (e.g., in König 'king', fertig 'ready', Leichtigkeit 'ease, facility' or erniedrigt 'humiliated'), whose pronunciation as either a fricative or a plosive variant has been a controversial issue since the beginning of the codification of standard German (see section 3.1). The variation of this particular phenomenon is controlled by complex linguistic factors (e.g., phonetic context), which are partly codified in the standard language. However, the variation is also driven by sociolinguistic factors which account for the variation in the actual language use and which reflect regional and situationalpragmatic differences.

Our analyses are based on a substantial empirical corpus, comprising of linguistic data conducted from 52 speakers of two generations covering all major Austrian dialect regions. Elicitation settings varied from strongly standardized tasks with a graphic or at least visual stimulus (reading aloud tasks, picture naming tasks) to translation tasks (translation from dialect into standard) with oral stimuli. Our quantitative and qualitative results should enable us to answer the following key research questions:

- What is the relation between standard language pronunciation norms and standard language use in Austria?

- Which parallels and differences can be found in the pronunciation used in reading aloud tasks, picture naming tasks and translation tasks (towards standard) in Austria?

- What can be said about the intra- and inter-individual variation of the standard language spoken in Austria?

- Which parallels and differences can be found in the standard language use of different speaker groups in various regions across Austria? 
- Which regularities emerge which can be said to represent norms that define an Austrian standard?

- In what way are these norms Austria-specific and/or contrary to the norms reported for Germany?

The discussion is structured as follows: Section 2 focusses on theoretical and methodological aspects of standard language research on German in general, while section 3 discusses the variation of $\langle$-ig $\rangle$-pronunciation from the perspective of language norms and language usage by referring to existing research. Section 4 is devoted to our own empirical study of the variation phenomenon. The paper closes with a summary (section 5).

\section{German standard(s) from normative and from usage perspectives}

Concerning the definition of a German standard, an essential theoretical question is whether this variety can include regional variants (for the discussion of this topic see Schmidt \& Herrgen 2011, Herrgen 2015, Ammon et al. 2016, Deppermann et al. 2013, Maitz \& Elspaß 2013, Klein 2013 and Kleiner 2014). For example, according to Schmidt \& Herrgen (2011: 62), the German standard is defined as a variety which lacks salient regionalisms and therefore considers the listeners' judgements based on their norm concepts. In this context, the standard is largely associated with trained speakers and a small group of laypeople. For instance, by analyzing two German newsreaders, Lameli (2004: 86) demonstrates that trained speakers (in this case newscasters) from Germany deviate from the standard norm as it is codified in the German German pronunciation dictionary Duden (2015) only in every thirty-fifth or fortieth word. In contrast, even Northern German laypeople, who are often and transnationally associated with standard-closest articulation (see e.g., König 2008), diverge from the same codified German German standard norm in at least every fifth word (see Lameli 2004: 210-212), thus much more often than trained speakers. Based on these results, Lameli (2004) proposes to empirically and theoretically separate the German standard of trained speakers from the Kolloquialstandard "colloquial standard" of laypeople with few phonetic differences. In contrast to the "regional accent", which typically includes more (salient) regional variants, this "colloquial standard" appears to be judged as being "pure High German" by highly educated listeners from Germany. Thus, from the German (academic) listeners' perspective, there seems to be a kind of perceptive border between the standard variety including the "colloquial standard" on the one hand and the Regionalakzent 'regional accent' on the other hand.

Deppermann et al. (2013: 90) criticize Schmidt \& Herrgens' (2011) approach towards standards with regard to the fact that in their definition hardly any untrained speakers would achieve the ideal pronunciation. Instead, they argue for 
a "regional standard usage" (regionaler Gebrauchsstandard), which considers the "communicative events in which ordinary speakers take part, particularly in semiformal contexts". According to the authors, standard should be a variety which can be used for the majority of communicative events (at least by educated speakers) and should be comprehensible to the entire speech community. Their approach to Gebrauchsstandard 'regional standard usage' is further supported by Ammon (2005: 29), who defines standard as a general speech form in public language usage. Kleiner et al. (2011: 181) go even further and consider non-public formal language usage as being standard (usage). Empirically, the "standard usage" can be examined by reading tasks and sociobiographic interviews with pupils with a higher level of school education (see Kleiner 2014: 277). In this sociolinguistic usage-based approach, the Regionalakzent 'regional accent', is part of the standard, while in the aforementioned structural linguistics definition it is part of the "regiolect" and therefore of the nonstandard. Thus, Regionalakzent "regional accent' and Regionalstandard 'regional standard' are synonymous on the phonetic level (see Kleiner et al. 2011: 180-181).

The research debate demonstrates the complexities of defining a German standard and the many issues it presents. For instance, regarding the relation between "standard norms" and "real" language usage (by model speakers versus/and laypeople; in formal/public versus/and other contexts). In his "field of social forces of a standard variety" (Soziales Kräftefeld einer Standardvarietät, see Figure 1), Ammon (1995) brings four central interacting components of a standard variety together: A standard variety is codified in dictionaries, which define its form and features. Variants, which are colloquial or - in pluricentric contexts - part of another national variety, are specially marked. This codex is typically prescribed by state institutions and provides guidance for nationals, i.e. the members of a linguistic community. It is important to note that few members directly orient themselves to these norms. Instead, norm authorities, such as teachers and officials in state agencies, are obligated to apply the codex and pass it on to their pupils or employees. Thus, the corrections of norm authorities play a decisive role for the standard norm. Furthermore, language experts, i.e. linguists or university teachers, also participate in the norm-setting process and provide a professional opinion on the codex, which then might influence the future norm. Moreover, an important factor in setting norms is model speakers in the media, whose pronunciation serves as a prestige model for the speech community and pronounce texts intended for the public (model texts). It is important to note that feedback effects between all the components of the social forces model can be assumed. While norm authorities adjust themselves to model speakers during the norm setting, the model speakers' pronunciation is influenced by the standard, which they had learned during their speech training. Furthermore, norm authorities and language experts are interconnected in order to justify their decisions. A further influencing factor, which cannot 
be disregarded in this "field of social forces of a standard variety", is the pronunciation of the population. However, the population itself might be heterogeneous and has an indirect impact on the norm-setting process (see Ammon 1995: 73-81).

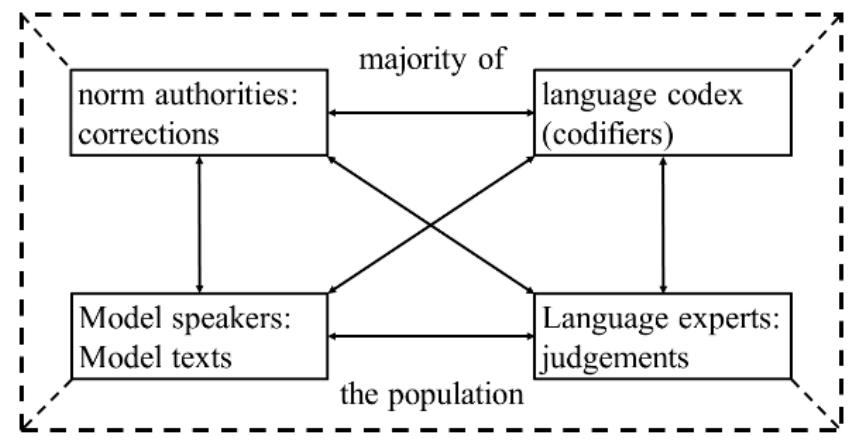

Fig. 1: Field of social forces of a standard variety (see Ammon 1995: 80).

Ammon (1995: 81) proposes that (phonetic) variants can be regarded as part of the national standard, when all four forces converge and therefore accept them as conforming to the standard. A clear delimitation is impossible in many cases, since many features are controversial between the entities and are only accepted as part of the standard by some of them. To consider the different components of the social forces model, the following section describes the Austrian language codex of $\langle$-ig $\rangle$ (section 3.1) and its pronunciation by Austrian model speakers and educated laypeople separately (section 3.2).

\section{State of research: Norm and pronunciation of «-ig〉 in Austria}

\subsection{Pronunciation norms and codices of "German" - Yesterday and today}

There are several reference guides for the different national (and regional) standards of German for the lexical level which are (predominantly) accepted by society and the linguistic community (see e.g., Bickel \& Landolt 2012, ÖWB 2016, Ammon et al. 2016). In contrast, there is no undisputed pronunciation dictionary or codex that defines (or describes) the phonetic norms of Austrian standard German. However, several attempts were made to describe prominent features of Austrian standard pronunciation in contrast to German German standard (see Moosmüller et al. 2015, Muhr 2007, Wiesinger 2009a). Nonetheless, regarding many Austrian pronunciation issues, the normative character remains unclear.

In 1898, the first pronunciation norm of standard German was published, namely Theodor Siebs' "Deutsche Bühnenaussprache" 'German stage pronunciation' (Siebs 1898). The aim was to establish the existing language usage on stages 
as pronunciation norm and to counterbalance differences resulting in a pronunciation norm for the guidance of actors. Since 1922, the reine Hochlautung 'pure high pronunciation' was also prescribed in schools. In 1969, criteria for the modified version were proposed in a gemäßigte Hochlautung 'moderate high pronunciation'. While the reine Hochlautung 'pure high pronunciation' was described as an ideal norm, obligatory for theatres, poetry and classical singing, the gemäßigte Hochlautung 'moderate high pronunciation' was intended to represent the standard norm of laypeople. The "ideal standard norm" would only exhibit one variant whereas a range of variation could be proposed for the "standard usage". For instance, special regional rules were applied for Austria and Switzerland (see Siebs 1969: 1-15). The case of $\langle-\mathrm{ig}\rangle$ is a frequently discussed phenomenon in this context (see also Kleiner 2010: 260-262). At the offset of a syllable (König 'king') or before consonants (befriedigt 'satisfied', freudigste 'happiest'), Siebs (1969: 100, 113-114) recommends a fricative pronunciation [iç] to represent the reine Hochlautung ('pure high pronunciation'). In contrast, before -lich (an adjectival suffix) and in the word Königreich 'kingdom' - where there are already fricatival [Iç]-contexts (orthographically transcribed as $\langle\mathrm{ch}\rangle$ ) - the plosive variant [ik] is proposed. Furthermore, before vowel (e.g., ewiges 'eternal'), 〈-ig〉 should be pronounced as a voiced plosive [Ig]. Hoewever, for the Austrian gemäßigte Hochlautung 'moderate high pronunciation' the plosive pronunciation [Ik] is permitted in all phonetic contexts.

Luick (1996 [1904]) criticized Siebs' (1898) language conventions and argued that they could not be applied to Austria. Overall, he concluded that it is impossible to set one norm for the whole German speaking area. Instead, he argued that a norm should be installed and formulated for each individual area. To describe the norms for Austria, he examined the pronunciation of educated people from Vienna and other federal states of Austria. Concerning <-ig), he concluded that the colloquial Austrian German varies between [ç] and [k]. Thus, for Luick (1996 [1904]) the language usage at the beginning of the 20th century is not clearly differentiated. Regarding the writing classes as a school subject, Luick (1996 [1904]: 92) recommends the plosive variant, but in other settings, particularly in declamations, [ç] should not be corrected. Luicks (1996 [1904]) pronunciation recommendations, however, have never led to a codification of standard Austrian German. Instead, an Austrian supplement was attached to Siebs' "Bühnenaussprache" 'German stage pronunciation' in 1957, which established pronunciation guidelines for Austrian schools. Regarding 〈-ig〉, the guidelines generally provide a fricative pronunciation, but plosives are permitted before /s/, /st/ and /t/ in Austria as well (see Luick 1996 [1904]: 140).

The most differentiated and recent description of the German standard is presented in the (newly edited) pronunciation dictionary of Duden (2015), which defines standard language as a usage norm (see section 2 for definition) considering trained speakers as well as laypeople's pronunciations. The Duden (2015), 
which is clearly a descriptive rather than a prescriptive pronunciation dictionary, focusses on the German German standard, but also considers norm differences in Austria and Switzerland. Concerning <-ig), the Duden (2015: 462) describes the pronunciation by differentiating four phonetic contexts:

1. In the final position of adjectives (e.g., schmutzig 'dirty'), numerals up from 20 (e.g., zwanzig 'twenty'), some nouns (e.g., König 'king') and some place names (e.g., Leipzig) [Iç] is used by German professional speakers and laypeople from northern Germany. In contrast, in eastern Austria the fricative occurs alongside [Ik]. [Ik] is spread generally in wide areas of southern Germany and in western Austria. Furthermore, the $\langle$-ig〉-pronunciation depends on the formality of the speech situation. For instance, in northern Bavarian [Ik] only occurs in formal situations.

2. Before voiceless consonants $/ \mathrm{t} /$ and $/ \mathrm{s} /$ in suffixes (e.g., erledigte 'finished') superlatives (e.g., wichtigste 'most important'), ordinals (e.g., zwanzigste ('twentieth'), before -keit (e.g., Schwierigkeit 'difficulty') [Iç] is used by professional speakers and predominantly in northern German laypeoples' reading pronunciation. In contrast, in Austria and wide areas of southern Bavaria [Ik] is used. Exceptions are ordinal numbers and words with -keit, which are often pronounced with [Iç] even in these regions.

3. Before vowels and syllabic nasals in inflected forms of verbs (e.g., erledige 'finish'), adjectives (e.g., wichtigen 'important') and substantives (e.g., Käfige 'cages') the plosive realization [Ig] is common.

4. Before-lich (e.g., königlich 'royal') and -reich (e.g., Königreich 'kingdom') the pronunciation is [Ik].

Despite the assumption of a usage norm, the Duden (2015) glossary only lists the supra-regional variants from German trained speakers (here: [Iç]), while variation between the national standards are described separately. However, the [Ik]-pronunciation is accepted as being completely norm-compliant (see Duden 2015: 432).

There are two recent pronunciation dictionaries regarding the $\langle$-ig $>$-pronunciation (and other phonetic phenomena) which concentrate on Austrian standard German, namely Muhr (2007) and Wiesinger (2009a):

In his (often criticized) pronunciation dictionary (see e.g., Kleiner 2008, Hirschfeld 2009 and Wiesinger 2009b), Muhr (2007) examines two model speakers (news anchors) for Austria. The results are used as a recommended orientation for presentations in public and media situations. Concerning <-ig), Muhr (2007: 50-51) describes a plosive pronunciation in the phonetic contexts before $/ \mathrm{t} / \mathrm{and}$ $/ \mathrm{s} /$. In contrast, for <-ig) in final position and before -keit (e.g., Süßigkeit 'sweetness'), he states both variants, namely [ik] and [iç].

Within the Deutsches Aussprachewörterbuch 'German pronunciation dictionary' by Krech et al. (2009), Wiesinger (2009a) describes the «-ig〉-pronunciation 
more comprehensively within three "registers of standard pronunciation" in Austria: I. the upper (gehobener) standard of trained speakers, which is similar to Siebs (1969) conventions with few Austrian particularities; II. the moderate (gemäßigter) standard of trained speakers based on Siebs (1969) with considerable Austrian speech features; and III. the standard of laypeople, which can be described as a "regional standard on a dialect basis" (Wiesinger 2009a: 235). According to Wiesinger (2009a), all three registers are distributed in the Austrian media. While news anchors and moderators typically pronounce register I or II, register III occurs in politicians and other persons of public interest from economics, science and culture. Concerning 〈-ig〉, the plosive [ig̊] typically occurs in register III, in contrast to registers I and II, where the fricative seems to be predominant, yet with assumedly increasing acceptance towards the plosive (see Wiesinger 2009a: 247). It is only in instances when $\langle-\mathrm{ig}$ 〉 is followed by a palatal fricative that it is pronounced as [ig̈] (e.g., lediglich 'only', Königreich 'kingdom') in accordance with Siebs. According to Wiesinger (2009a: 252), registers I and II reflect the Austrian standard, since this pronunciation of trained speakers is accepted all over Austria, while register III is restricted as a "regional standard" that is not valid in all areas of the country.

\subsection{The pronunciation of $\langle-\mathrm{ig}\rangle$ in Austria - Research to date}

\subsubsection{Empirical analyses on (trained) model speakers}

We can refer to previous studies on the $\langle$-ig〉-pronunciation by (linguistically) trained "model speakers" (see section 2 above). Their results will be chronologically summarized in the following:

Takahashi (1996) examines the question of whether the regularities of the proposed norms (e.g., Siebs, Duden) are reflected in the everyday language, and therefore whether differences occur between codices and the actual language use of "model speakers". Thus, he investigates Austrian newscasters from the ORF (the state-owned official Austrian broadcasting station) and teachers of German as a foreign language. Concerning 〈-ig〉-pronunciation, Takahashi (1996: 171) predominantly finds a plosive pronunciation like [Ik] in final position with the [rç]-pronunciation in dreißig 'thirty' as only exception. Unfortunately, no further information is provided concerning differences between the speaker groups, word class or diverging phonetic environments.

Wonka (2015) also examines the pronunciation of journalists during ORF news programs. The results demonstrate that $76.3 \%$ of the investigated lexemes are pronounced with plosive, while a fricative pronunciation occurs at a rate of $23.7 \%$. Gender appears to be an influencing factor, since male anchors use fricatives almost three times as frequently $(34.27 \%)$ as females $(12.86 \%)$. Furthermore, the factor of text type (report vs. moderation) is examined. While in reports the variants [iç] and [ [k] are very balanced, [ik] is prevalent (about 80\%) in live 
moderations (see Wonka 2015: 142-143). Wonka (2015: 150-153) differentiates her results with regard to the phonetic environment. In the final position, before $/ \mathrm{t} /$ and $/ \mathrm{s}(\mathrm{t}) /$ relatively similar results could be shown, namely ca. $22-25 \%$ fricatives. Furthermore, the category "middle of the word" is defined, which includes words ending in -keit as well as compounds as dreißigjährig 'thirty-year-old'. Here, only $13 \%$ fricatives occur. Unfortunately, the speakers' origins are not considered and statistical evidence for the different factors is missing.

Hildenbrandt \& Moosmüller (2015) also analyze newscasts of the ORF, demonstrating that plosive and fricative realizations are balanced $(53 \%$ plosive vs. $47 \%$ fricative). As an additional parameter, Hildenbrandt \& Moosmüller (2015: 120) suggest that regional differences within Austria could have an impact on the complex topic. They hypothesize that news anchors from western Austria pronounce more plosives than those from eastern Austria. Interestingly, although western Austrian news anchors use slightly fewer fricatives, this difference does not reach statistical significance. However, it is worth noting that the interspeaker variability is high. Regarding the phonetic context, Hildenbrandt \& Moosmüller (2015) observe that news anchors use 67\% plosives and 33\% fricatives in word-final position. Interestingly, in numerals news anchors produce the most fricatives $(82 \%)$. Before $/ t /, 38 \%$ of all instances are fricatives and thus comparable to the word-final position. Furthermore, in contrast to Wonka's (2015) results, the data indicate that news anchors produce $42 \%$ fricatives in superlatives, $59 \%$ in ordinals, and $83 \%$ before -keit.

In her master's thesis, Thévenanz (2018) also examines news casts from the ORF. Again, the results demonstrate a balanced distribution of plosives $(56 \%)$ and fricatives (44\%). In total, most $<$-ig) were collected in final position and in cardinal numbers. Divided according to the phonetic context, fricatives mostly occur before -keit $(100 \%)$, then in final position in cardinals $(62 \%)$ and in final position in adjectives and substantives (21\%). The other contexts are under-represented, but the few items demonstrate that preceding $/ \mathrm{st} / 26 \%$ fricatives occur and before $/ t / 15 \%$. Furthermore, Thévenanz (2018: 51-52) indicates that, in total, men use [Ik]-variants more frequently than women, but because of high interpersonal variability, more statistical evidence is needed to substantiate this finding.

\subsubsection{Empirical analyses of ("untrained") academics}

There are some studies which concentrate on the pronunciation of $\langle-$ ig $\rangle$ (amongst others) in standard language usage of highly educated Austrian laypeople:

A groundbreaking work for this analysis is König (1989a, 1989b), which, for the first time, aimed to empirically explore and outline regional differences in the pronunciation of written German on a larger database. He recorded students from 
44 locations in Germany, during reading a word list. For 〈-ig〉 the results demonstrate clear differences between northern Germany ([Iç]) and southern Germany ([Ik]) (see König 1989b: 319). Interestingly, in words containing -keit, fricatives occur even in southern Germany, while in words like königlich 'royal' and Königreich 'kingdom' plosives occur almost exclusively even in northern Germany (see König 1989a: 117-118).

König's (1989) investigation was limited to the former federal states of Germany, but Kleiner (2010) conducted an expanded survey, which included Germany in its entirety, as well as Austria and other German speaking countries. His corpus predominantly consists of recordings of pupils from the Gymnasium (advanced secondary school) located in 170 locations (see for colored maps Kleiner $2011 \mathrm{ff}$ ). The analysis of $\langle-\mathrm{ig}\rangle$ is based on word lists and texts, which are read aloud, translations from English to German and language biographical interviews. Kleiner (2010) analyzes <-ig) depending on its phonetic environment. He differentiates $\langle$-ig $\rangle$ in final position, $\langle-\mathrm{ig}\rangle$ before $[\mathrm{t}] /[\mathrm{t} ə],\langle-\mathrm{ig}\rangle$ before $[\mathrm{s}] /[\mathrm{st}],\langle-\mathrm{ig}\rangle$ before -keit and 〈-ig〉 in special cases like Königreich 'kingdom', königlich 'royal' and Königshaus 'royal house'. Regarding Austria, Kleiner (2010: 268279) finds predominantly plosives in final position. The only tendency for fricatives can be found in eastern Austria, where emphasis varies in different words. For example, in richtig 'right' more fricatives occur than in einig 'agreed'. While fricative pronunciation increases for cardinal numbers in the whole of Germany, in western Austria plosives occur almost exclusively. Only further east from Salzburg - Gmunden - Tamsweg fricatives occur alongside plosives. The substantive König 'king' shows the clearest east-west differentiation. According to Kleiner (2010: 279), the <-ig)-pronunciation in substantives is more salient to speakers and therefore this areal distribution displays a conscious adaptation to the [Ik]-variant, which is considered to be correct pronunciation in many regions. The Austrian data also show that $\langle$-ig $\rangle$ before $[\mathrm{t}] /[\mathrm{t}$ ?] and before $[\mathrm{s}] /[\mathrm{st}]$ is predominantly pronounced as a plosive, although slight deviations occur between different words of the categories, for instance between superlatives and ordinal numbers ending with -igste(n). The suffix -igkeit is a special case, as it demonstrates most fricatives even in eastern Austria, whereas in western Austria plosives are again predominant. Finally, in the words Königreich 'kingdom', $k \ddot{o}-$ niglich 'royal' and Königshaus 'royal house' [rk]-variants were attested in the whole study area. Apart from the areal distribution and dependence of the phonetic environment, Kleiner (2010) discusses the different contextual styles in spelling pronunciations in contrast to spontaneous speech. For instance, he demonstrates that using displayed numbers (instead of spelled numbers; comparable to picture naming tasks) is useful when collecting the "standard usage", since very similar results were found in instances such as interviews (see Kleiner 2010: 276). Kleiner (2010: 299) concludes that western Austria, with a focus on 
the state of Tyrol, is one of the most stable plosive areas, explicable by the vital dialects, which predominantly lack any [ç]-allophone.

Besides the aforementioned studies, there are investigations which focus primarily on Austria. For instance, Bürkle (1995) recorded 15 speakers from all over Austria with Matura (general qualification for university entrance) during which the speakers read aloud from a word list. Results demonstrate that fricative pronunciations only occur in Obrigkeit 'authority' (3 times), ewig 'eternal' ( 2 times) and König 'king' (1 time). He concludes that $<$-ig〉 before -keit is mostly pronounced as a fricative. The results for the rest of $\langle-\mathrm{ig}\rangle$-pronunciations remain unclear, as does the areal distribution of the pronunciations.

Ehrlich (2009) analyzes phonetic standard features by asking students to read a word list. The results demonstrate a general preference for a pronunciation with plosive. Interestingly, in the final position, a fricative is used in about $30 \%$ of the cases, while before $/ \mathrm{t} /$ and $/ \mathrm{s} /$ fricatives occur in up to $20 \%$. Furthermore, Ehrlich (2009: 111-112) finds that häufigsten 'most frequently' is pronounced significantly more often with plosive in Vienna than in the other Austrian federal states. For the other words, no significant effects could be found with reference to the areal distribution of the participants.

Thévenanz (2018) conducted a survey with 30 students or graduates from Austria. Participants were required to perform several tasks: picture naming, translation of English sentences, reading German sentences, and interviews. Concerning $\langle-\mathrm{ig}$, in total, $76 \%$ were articulated as plosives, $24 \%$ as fricatives. Surprisingly, no differences could be detected between the different elicitation settings, although the picture naming evoked a slightly higher degree of fricatives. Again, most fricatives occur before -keit (80\%), then in final position in cardinals $(40 \%)$, in final position in adjectives and substantives (12\%), preceding /st/ $(7 \%)$ and /t/ $(6 \%)$. Interestingly, in contrast to her study on news anchors, Thévenanz (2018: 73-74) found no evidence of gender differences. However, she found differences regarding the origin of the speakers. Unfortunately, these differences only display tendencies, since the number of speakers from the locations is inconsistent. While the results for Vienna, Lower Austria and Upper Austria display the average, speakers from Salzburg and Carinthia use a lot more plosives. In contrast, the only speaker from Styria shows the most fricatives.

Amongst others, Hildenbrandt \& Moosmüller (2015) recorded semi-structured interviews with 12 highly-educated speakers from Vienna. Overall, speakers pronouncing $<-i g$ ) use $88.5 \%$ plosives and thus much fewer fricatives $(11.5 \%)$ than news anchors (47\%). Interestingly, there is a high inter-speaker variability showing that some speakers never use fricatives, while others use them in more than $30 \%$ of the cases. Gender, however, does not play a decisive role. Hildenbrandt \& Moosmüller (2015: 121) conclude that "the fricative pronunciation of $-i g$ is rather not a trait of SAG [Standard Austrian German] speakers". For 
further analyses, Hildenbrandt \& Moosmüller (2015: 122-124) use the phonetic contexts displayed by Kleiner (2010). Their speakers use $83 \%$ plosives in wordfinal position ( $80 \%$ in numerals). Interestingly, this is contrary to the usage of the news anchors, who produce plosives in numerals only in $18 \%$ of the cases. Unfortunately, not enough data is available for the remaining positions. However, these few items indicate that, in accordance with Kleiner (2010), 〈-ig〉 preceding -keit is overwhelmingly produced with fricative. Hildenbrandt \& Moosmüller (2015: 126) conclude that "SAG [Standard Austrian German] speakers, all from Vienna, predominantly make use of the stop pronunciation, with an exception of -ig preceding -keit. Definitely, the investigation need to be extended to SAG [Standard Austrian German] speakers from other parts of the country". It is this gap in research that the survey presented in this paper intends to close.

\subsubsection{The pronunciation of $<-i g\rangle$ in Austrian nonstandard varieties}

Although the main objective of this paper revolves around standard articulation and competing norms regarding the variation of $\langle-\mathrm{ig}\rangle$, the assumption is that the "underlying" dialectal structure is likely to play a considerable role for the explanation of specific regional differences. Regarding Austrian dialects, the plosive can be considered as a 'default' pronunciation with frequent $g$-deletions in wordfinal position (e.g., flaißßßi 'diligent' (Kranzmayer 1956: 85)), the latter especially in the eastern states of the country. In addition, Luick (1996 [1904]: 92) describes the additional use of fricatives in (eastern) Austrian dialects, resulting in three possible realizations of 〈-ig〉, especially in the area of Vienna: /-i/, /-iç/ or /-igg, ik/ (see Hildenbrandt \& Moosmüller 2015: 113 and 115). At the same time, though, Luick (1996 [1904]: 92) attests a preference for plosives based on the written language, perceived as the correct standard form. The result is, as Hildenbrandt \& Moosmüller (2015: 113) conclude, the "paradoxical situation", in which "in the eastern parts of Austria, SGG [Standard German German] norms and dialectal usage coincide", both favoring the fricative pronunciation. These findings are partially confirmed in their own study, in which speakers of Viennese dialect use more fricatives than speakers of standard Austrian German (21\% vs. 12\%), especially in word-final position ( $38 \%$ vs. $17 \%$ ).

Elspaß \& Möller (2003ff) provide an insight into 〈-ig〉-variation of "intermediate varieties" ("regiolect", see Lenz 2010) with the "Atlas zur deutschen Alltagssprache" (ADA) 'Atlas of colloquial German'. In their first collection round they collected data, between 2003 and 2004, from 1763 participants from 440 locations, via an online survey. For the words König 'king', wenig 'few' and zwanzig 'twenty', they demonstrate again that in Austria 〈-ig〉 predominantly is pronounced like [Ik], although some fricatives also occur. These generally appear in eastern Austria, although some can be found in western Austria as well. 


\section{The present study}

\subsection{Research questions}

In the introduction of our contribution (see section 1) we formulated the general research questions of our study. Regarding the concrete variation phenomenon (i.e., the <-ig)-pronunciation in Austria), these previous research questions can be specified as follows:

- What is the relation between standard language pronunciation norms and standard language use in Austria with regard to the realization of unstressed $\langle-$ ig $\rangle$ ?

- Which parallels and differences can be found in the pronunciation of 〈-ig〉 used in reading aloud tasks, picture naming tasks and translation tasks in Austria?

- What can be said about the individual and inter-speaker variation of 〈-ig〉realization in Austria?

- Which parallels and differences can be found in the realization of unstressed 〈-ig〉 in standard intended or formal speech contexts of different speaker groups in various regions across Austria?

Previous studies investigating the pronunciation of $\langle-\mathrm{ig}\rangle$ in Austria predominantly concentrate on model speakers, such as newsreaders or educated speakers including students or pupils from the Gymnasium. Therefore, data from other social groups (especially older speakers) are rare. Furthermore, apart from Kleiner (2010), a structured comparison based on the same methodology between different regions of Austria remains a major research desideratum. This paper addresses these research gaps and aims to answer the above research questions using a large database. This database includes language material from (linguistically) untrained Austrian speakers from two generations, from thirteen different locations all over Austria. In contrast to previous studies, only villages (500 2000 inhabitants) are considered. In particular, we examine whether, and to what extent, any linguistic (phonetic context, part of speech, setting) or sociolinguistic factors (gender, age, origin of speakers) influence the $\langle$-ig〉-variation.

\subsection{Methodological approaches}

To answer these research questions, and to make comparisons with the aforementioned studies, we draw upon a large-scale and multidimensional corpus: Our data consist of material from the special research programme "German in Austria. Variation - Contact - Perception" (Spezialforschungsbereich (SFB) "Deutsch in Österreich. Variation - Kontakt - Perzeption") (see Lenz 2018, Budin et al. 2018, and Budin et al. 2019 for more information). The analyzed data comprise records of translation, reading and picture naming tasks. These data will be available via 
an online platform in the future. During the translation task, the participants were asked to translate the so-called "Wenker sentences" (Wenkersätze) into their 'best' "High German" or into their local dialect. As a stimulus, each sentence was presented orally (by means of a laptop) - spoken either by proficient dialect speakers for each of the selected villages or by a professional news broadcaster - and was immediately translated into the respective other variety. The aim of this method is to capture, in particular, the participants' concepts of their own "most standardapproximation" or "most dialectal" language competence. In addition, due to the (rather) closed setting with limited options for modification, inter-individual comparability among the analyzed participants, and to similar projects, is offered (e.g., REDE, see Ganswindt et al. 2015). Alternative tasks were, of course, performed in between in order to account for learning effects (see Lenz 2018).

In order to not only analyze responses to orally induced tasks, written stimuli were introduced in the reading tasks. While the participants were required to concentrate on sentence-to-sentence-translations during the "Wenker translation task", the exact articulation of each word was now the object of research. All participants were required to read a short text entitled Nordwind und Sonne "north wind and sun', as well as isolated words (in randomized order) designed for different phonological conditions (e.g., initial position, phonetic environment etc.). As part of the word list, some words were also presented as picture stimuli and were required to be named by the participants. Consequently, comparison between written and pictured items yield additional information regarding the influence of medial literacy and so-called 'spelling pronunciation'. Because the grapheme $\langle\mathrm{g}\rangle$ is expected to influence the participant's responses, we predicted that the highest rate of plosives would occur in the reading tasks. As Kleiner (2010: 267) indicates, reading tasks are not necessarily an artificial or unrealistic method of producing language. Instead, they also represent a projection of the participants' ideal model pronunciation. Thus, by analyzing reading articulation, major insights can be gained regarding individuals' normative concepts of pronunciation.

Our data comprise 〈-ig〉-realizations of 30 lexemes. Most of them hold 〈-ig〉 in final position ( $\mathrm{n}=17)$ : artig 'well behaved', einig 'agreed' (2x), fertig, 'ready', geläufig 'common, familiar', Honig 'honey', König 'king', lustig 'funny', richtig 'right', vierundvierzig 'forty-four', zwanzig 'twenty' as well as the numbers 20 , 33, 44, 66, 99 and 2033. In addition, other positions are accounted for: before vowel (derjenige 'the one (who)', häufiger 'more often', wenige 'few', wenigen 'few'), before plosive in -keit (Kleinigkeit 'little thing, trifle', Tätigkeit 'activity, occupation') and /t/ (beleidigt 'sulky', erledigt 'done, exhausted'), before the fricative /s/ (gefälligst 'kindly', wichtigste 'most important', 30.) and before liquid followed by a palatal fricative in -lich (königlich 'royal', lediglich 'merely'). Out of all words, 14 can be classified as adjectives, 9 as numerals, 4 as nouns, 2 
as adverbs and 1 as pronoun. Most of the lexemes $(\mathrm{n}=16)$ are part of the word list (beleidigt 'sulky', einig 'agreed', erledigt 'done, exhausted', gefälligst 'kindly', geläufig 'common, familiar', häufiger 'more often', Kleinigkeit 'litte thing, trifle', königlich 'royal', lediglich 'merely', lustig 'funny', richtig 'right', Tätigkeit 'activity, occupation', vierundvierzig 'forty-four', wenige 'few', wichtigste 'most important', zwanzig 'twenty'), while 3 items (derjenige 'the one (who)', einig 'agreed', wenigen 'few') belong to the text 'north wind and sun'. In the "Wenker translation task" only 2 lexemes containing 〈-ig〉 occur (artig 'good, well behaved', fertig 'ready'). The remaining 9 items are part of the picture naming task including pictures and numbers (Honig 'honey', König 'king', 20, 33, 44, 66, 99, 2033, 30.)

Occasionally, the number of total items varies for specific lexemes because of lexical modifications (e.g., more common brav instead of old-fashioned artig 'good, well-behaved') carried out by participants or due to interruptions during data collecting (e.g., background noise and laughing). During the "Wenker translation task", each sentence was translated twice: from dialect to standard and vice versa. In combination with the word list, this results in a total number of 1550 items in standard intended settings and 76 additional lexemes in the dialect translation task.

The data were collected from 13 villages (with a population of 500-2.000 inhabitants), evenly distributed across Austria's major dialect regions (see Figure 2): Raggal in the (Highest) Alemannic region; Tarrenz in the Alemannic-Bavarian transition area; Tux, Weißbriach and Oberwölz as part of South Bavarian; Hüttschlag, Passail and Neckenmarkt in the South-Central Bavarian transition area, and Taufkirchen, Steyrling, Neumarkt/Ybbs and Allentsteig as representatives of Central Bavarian.

For each village, four speakers were analyzed ( $=52$ in total), differing in age, mobility and educational background: 26 young women and men (avg. 26 years) with a high formal educational background (at least Matura), in contrast to 26 older participants (avg. 72 years) representing classical NORMs and NORFs (non-mobile, old, rural, male/female, see Chambers \& Trudgill 1993: 29). Unfortunately, we could not find participants who met our sociodemographic criteria in Taufkirchen (older, female) and Neckenmarkt (older, male). As a compensation, in both villages, a second older person of the same sex was added for the analysis. All participants can be considered as autochthonous members of their village, as they grew up and spent most of their lives there and have at least one parent from the respective location. Regarding the analysis, the previously mentioned lexemes were transcribed phonetically and controlled by a second phonetician. 


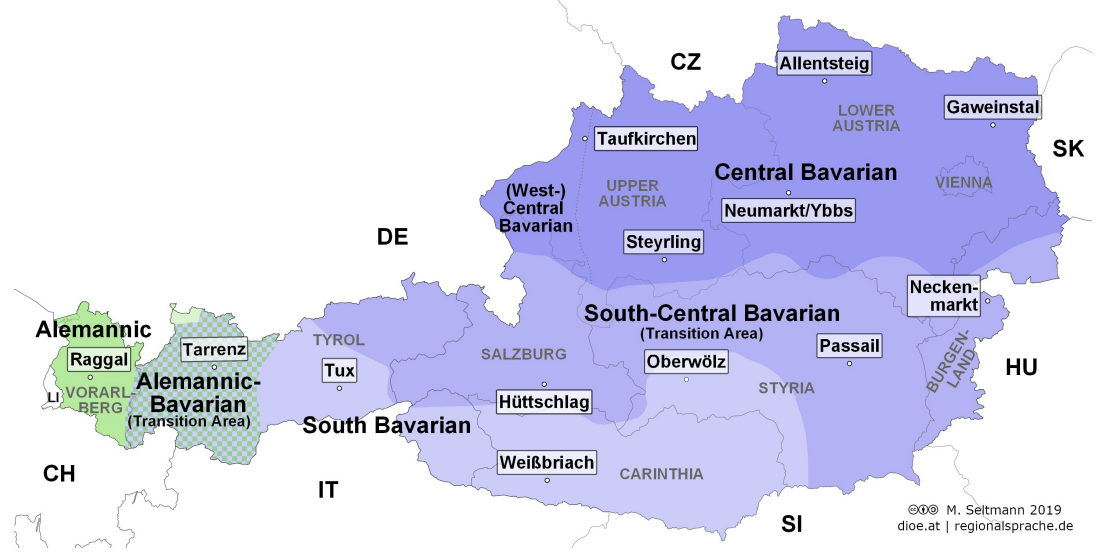

Fig. 2: Geographical and linguistic distribution of all 13 analyzed locations.

\subsection{Results and Interpretation}

In the following section, the discussion of the results is divided into linguistic and sociolinguistic factors. For the statistical analysis, we used the lme 4 package (Bates et al. 2015) of R (R Core Team 2018) to conduct generalized linear mixedeffects models (glmer) of the relationship between two possibilities of 〈-ig)-realization (fricative vs. plosive) and different participants, stimulus and procedure variables. Fixed participant variables were GENDER, GENERATION and DIALECT REGION, whereas fixed stimulus variables were PHONETIC CONTEXT and PART OF SPEECH. A fixed variable related to the procedure was the SETTING (reading or non-written speech samples). Participant ID, as well as stimulus ID, were entered as random variables. The dependent variable was binomial, i.e., 〈-ig〉-realization containing a fricative was coded as 1 and $\langle$-ig $\rangle$-realization containing a plosive was coded as 0 . Other variants as well as forms which could not be identified as containing clear fricatives or plosives were classified as "Other". Due to their small numbers, we did not include them in the statistical analysis.

\subsubsection{General results}

In total, $1550<$-ig〉-occurrences were examined in our data corpus, articulated by 52 participants in various "standard intended settings", i.e., reading a word list and a text aloud, naming pictures, and translating dialect sentences into "best High German". The setting, in which participants had to translate standard sentences into their local dialect, was not included in these results. These will be considered separately in section 4.3.5.

Irrespective of the survey setting, $90.8 \%$ of all pronunciations are plosives with different phonetic characteristics, namely $[\stackrel{\circ}{\mathrm{g}}]$, $[\mathrm{k}]$ or $\left[\mathrm{k}^{\mathrm{h}}\right]$ (see Figure 3 ). The fricative pronunciation [ç] occurs in $8.1 \%$ of the cases. Furthermore, some other 
realizations, like the deletion of $[\mathrm{k}](0.3 \%)$ or the deletion of $[\mathrm{I}](0.1 \%)$ and uncertain cases $(0.8 \%)$ could be detected. In sum, these further realizations make up only $1.1 \%$ of all cases. Therefore, these variants are summarized under the label of "Other" hereinafter.

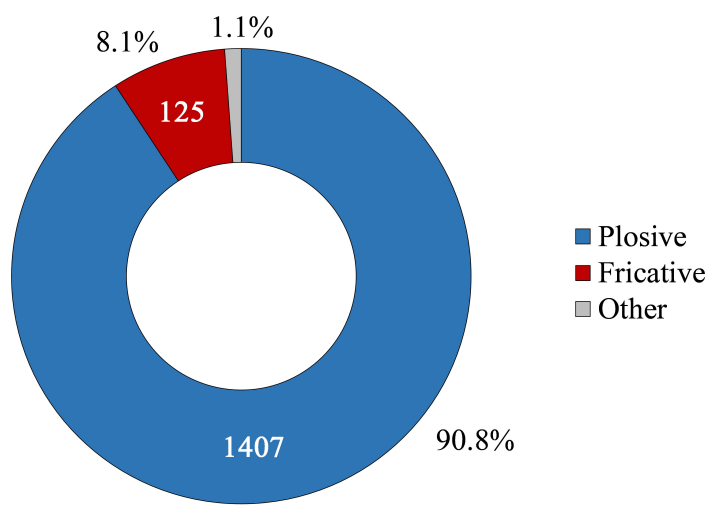

Fig. 3: $<-$ ig $>$-pronunciations in total $(\mathrm{n}=1550)$.

\subsubsection{Linguistic factors (phonetic context, part of speech)}

The pronunciation of <-ig) was examined in different phonetic contexts, namely in final position $(n=874)$ and before plosive $(n=208)$, before fricative in $/ \mathrm{st} /$ $(\mathrm{n}=156)$, before liquid followed by a palatal fricative in -lich $(\mathrm{n}=104)$ or before vowel ( $\mathrm{n}=208)$ (see Figure 4). As Figure 4 indicates, [iç]-occurrences mostly appear before plosives (18.8\%) and in final position (9.4\%). To investigate these contexts further, subcategories were defined. These show that, in the position before plosive, the morpheme -keit is responsible for most fricatives (36.5\%), while before $/ t /$ only $1 \%$ represents fricative-articulation. In final position, a subgroup was formed again, considering differing word classes. In contrast to substantives and adjectives with less than 5\% fricatives, cardinals were realized with [iç] in $14.7 \%$. Therefore, in total, most fricatives occur before -keit and in final position in cardinals. In contrast, before -lich and vowels, not a single fricative could be detected, whereas before /st/ few [iç] appear (2.6\%). Furthermore, we controlled the phonetic context following <-ig〉 in final position. For example, the lexeme einig 'agreed' occurs twice in our data, not only in the word list but also in the reading text followed by the word dass 'that'. However, no differences concerning $\langle$-ig $\rangle$-realization could be found in these contexts. 


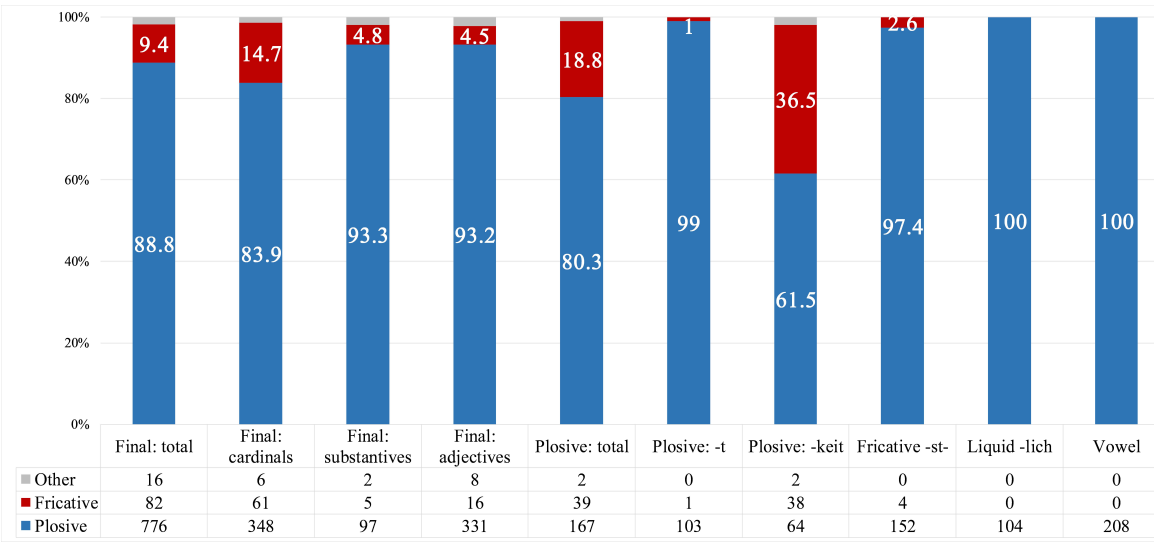

Fig. 4: 〈-ig)-pronunciations by phonetic context in $\%$ and absolute values ( $\mathrm{n}=1550)$, all "standard intended settings" taken together.

As the results above indicate, part of speech must be considered as a crucial factor for the variation of $\langle-i g\rangle$, in addition to the phonetic context. Hence, the following word classes were thoroughly examined: numerals $(n=467)$, substantives $(\mathrm{n}=208)$, adjectives $(\mathrm{n}=719)$ and others (pronouns and adverbs with $\mathrm{n}=156)$. In substantives, the highest number of fricatives is used (20.7\%), followed by numerals (13.8\%) (see Figure 5).

A subdifferentiation of the numerals in cardinals and ordinals, as well as substantives in simplicia and derivations, again demonstrates that cardinals (14.7\%) and derivations $(36.5 \%)$ are responsible for the higher rates of fricatives in these categories. In contrast, ordinals (5.8\%) and simplicia (4.8\%) present far less fricatives. Moreover, adjectives show only few fricatives $(2.5 \%)$, while in pronouns and adverbs only plosives are pronounced.

The results for phonetic context and part of speech are confirmed by the statistical analysis. Concerning the variable PHONETIC CONTEXT the analysis shows that before -keit $(\beta=5.845, \mathrm{SE}=1.024, \mathrm{Z}=5.707, \mathrm{p}=0.000)$ and in final position $(\beta=3.013, \mathrm{SE}=0.594, \mathrm{Z}=5.072, \mathrm{p}=0.000)$ fricatives occur significantly more often in comparison to all other contexts combined. This effect is most pronounced in -keit supporting that this is the context with most fricatives (just under $40 \%$ ). Furthermore, the statistical analysis of the variable PART OF SPEECH reveals that substantives $(\beta=3.284, \mathrm{SE}=0.877, \mathrm{Z}=3.74, \mathrm{p}=0.000)$ and cardinals $(\beta=3.107$, $\mathrm{SE}=0.754, \mathrm{Z}=4.123, \mathrm{p}=0.000)$ are significantly more often pronounced with fricatives than adjectives, adverbs and pronouns taken together. In contrast, ordinals do not show a significant effect in this regard $(\beta=0.828, \mathrm{SE}=1.035$, $\mathrm{Z}=0.800, \mathrm{p}=0.424)$. 


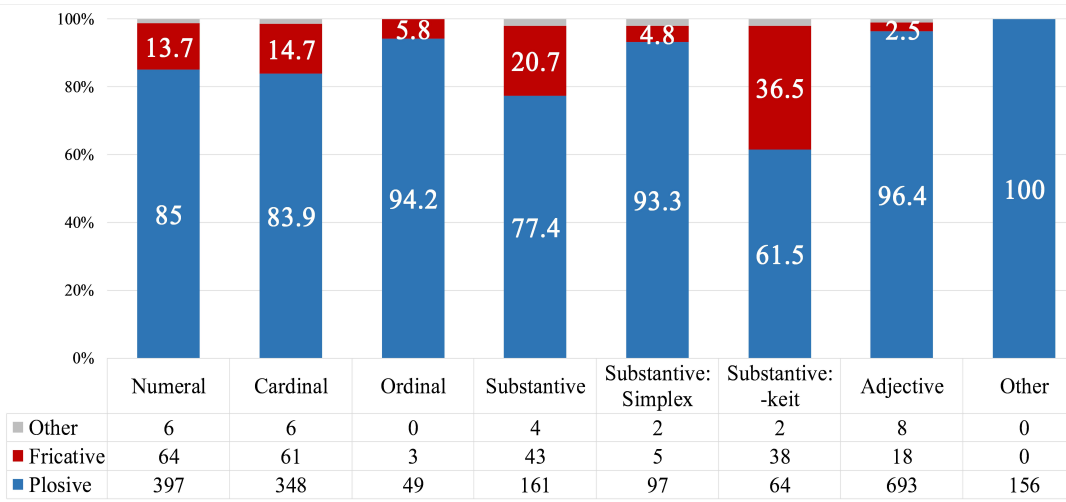

Fig. 5: 〈-ig〉-pronunciations by part of speech in \% and absolute values $(n=1550)$, all "standard intended settings" taken together.

\subsubsection{Effects of the survey setting (methodological influence)}

Former studies reveal that the survey setting has an influence on the pronunciation since reading texts or word lists may lead to a spelling pronunciation, which differs from spontaneous conversations in interviews etc. To investigate this connection in the present data, we compared written stimuli (word list $(\mathrm{n}=830)$ and text $(\mathrm{n}=156)$ ) versus non-written speech samples including picture naming tasks $(\mathrm{n}=468)$ and orally-induced translations from dialect to standard $(\mathrm{n}=96)$. In total, in our non-written data $(13.3 \%)$ more fricatives were pronounced than during reading (5.1\%). Examining the subgroups (see Figure 6), the results demonstrate that during the reading of a text the fewest [Iç]-variants were used (1.9\%) followed by the word list with $5.7 \%$.

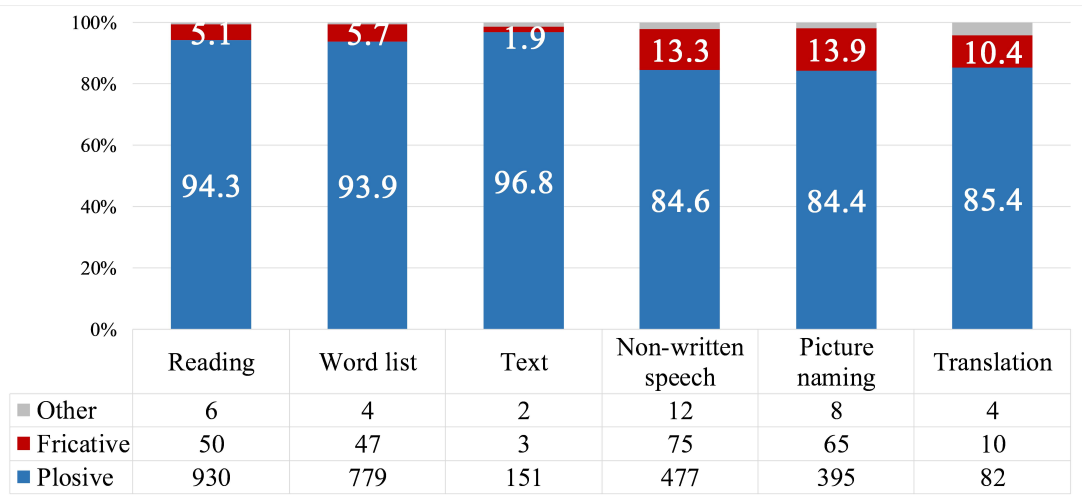

Fig. 6: <-ig)-pronunciations by setting in $\%$ and absolute values $(\mathrm{n}=1550)$, all "standard intended settings" taken together. 
Among the non-written speech samples, fricative pronunciations occur in $10.4 \%$ during translations and in $13.9 \%$ during picture naming. As the statistical analysis affirms, a great difference between reading and non-written speech samples can be attested $(\beta=-2.485, \mathrm{SE}=0.789, \mathrm{Z}=3.150, \mathrm{p}=0.002)$ with significantly less fricatives during reading. However, note that these results are influenced by the distribution of cardinals and derivations with -keit in the settings. While in non-written speech 6 out of $11(55 \%)$ lexemes are cardinals, in the reading setting only 4 out of $19(21 \%)$ lexemes are cardinals or derivations with -keit. Thus, this uneven distribution of lexemes, which evoke most fricatives in the data set, likely plays a decisive role for the differences between non-written data and reading aloud.

\subsubsection{Sociolinguistic factors (gender, age, regional background)}

Next to these intrinsic factors, which account for the $<$-ig)-variation in Austrian standard German, sociolinguistic factors also influence the $\langle$-ig〉-pronunciation.

In total, 774 variants of men and 776 variants of women were analyzed concerning <-ig〉-variation. Men use half as many fricatives $(5.3 \%)$ as women $(10.9 \%)$. Besides the general gender effect, it is interesting to consider whether there is an interaction between gender and age. We hypothesize that young women in this context function as 'trendsetters' and are more likely to take over German German standard norms. The results indicate a slight increase of fricatives, starting with old men $(4.6 \%)$, young men $(5.9 \%)$, old women $(10.3 \%)$ and young women $(11.4 \%)$ (see Figure 7). However, the statistical analysis regarding the variables GENDER and GENERATION reveals only a significant effect for GENDER $(\beta=1.145$, $\mathrm{SE}=0.533, \mathrm{Z}=2.148, \mathrm{P}=0.032$ ), showing than women use significantly more fricatives than men do but no effect for generation $(\beta=0.278, \mathrm{SE}=0.526$, $\mathrm{Z}=0.529, \mathrm{p}=0.597)$.

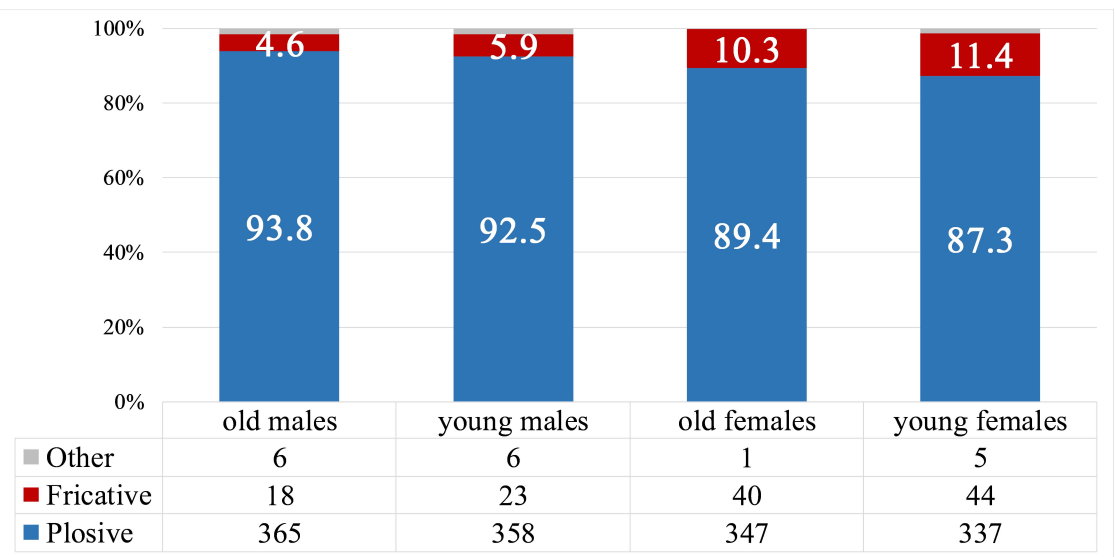

Fig. 7: 〈-ig)-pronunciations by gender and generation in $\%$ and absolute values $(\mathrm{n}=1550)$, all "standard intended settings" taken together. 
The results in phonetic context show that most fricatives occur before -keit and in final position in cardinals. Therefore, it is questionable as to whether differences between the generations and gender occur in these positions. Before -keit, fricatives constantly increase from old males $(11.5 \%)$ via young males $(23.1 \%)$, old females (38.5\%) to young females (73.1\%) (see Figure 8 ).

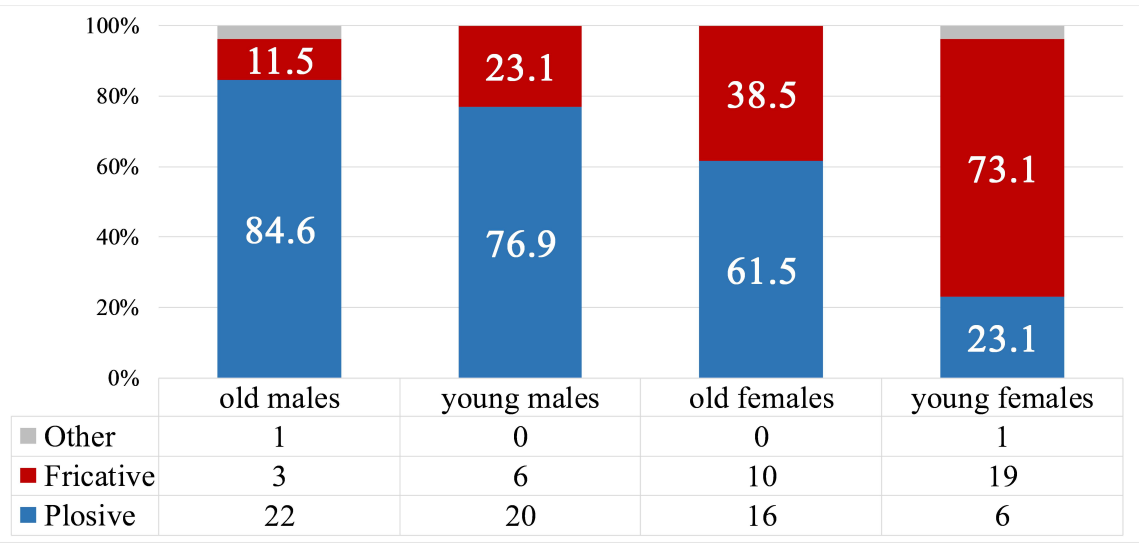

Fig. 8: 〈-ig)-pronunciations by gender and generation before -keit in \% and absolute values $(\mathrm{n}=104)$, all "standard intended settings" taken together.

However, in cardinals this effect to such a degree cannot be confirmed. Although old women use the most fricatives (23.1\%) and old men the fewest (9.6\%), [Iç] occurs approximately equally in the young generation (women: $13.6 \%$, men: $12.5 \%$ ). Nevertheless, in total, no significant effect could be proven regarding the factor GENERATION.

For the analysis of the regional distribution of 〈-ig , data from thirteen locations spread all over Austria were collected (see section 4.2). The main question is whether differences appear between the dialect regions, represented by the analyzed locations: Central Bavarian, South Bavarian and Alemannic as well as the transition zones. Figure 9 shows the results separated by gender and generation (above right: old females, above left: old males, below right: young females, below left: young males). Every pie chart represents up to $30<-\mathrm{ig}\rangle$-pronunciations (the number varies due to differing lexical choices made by the participants during the translation task). Since we lack language material from one old person from Taufkirchen and Neckenmarkt each, one value remains missing in the following Figures 9, 10 and 11 regarding these locations. To compensate for this, two persons of the same sex were considered yielding double the amount of $<-$ ig $\rangle-$ pronunciations by speakers (in Figure 9: 60 instead of 30). 


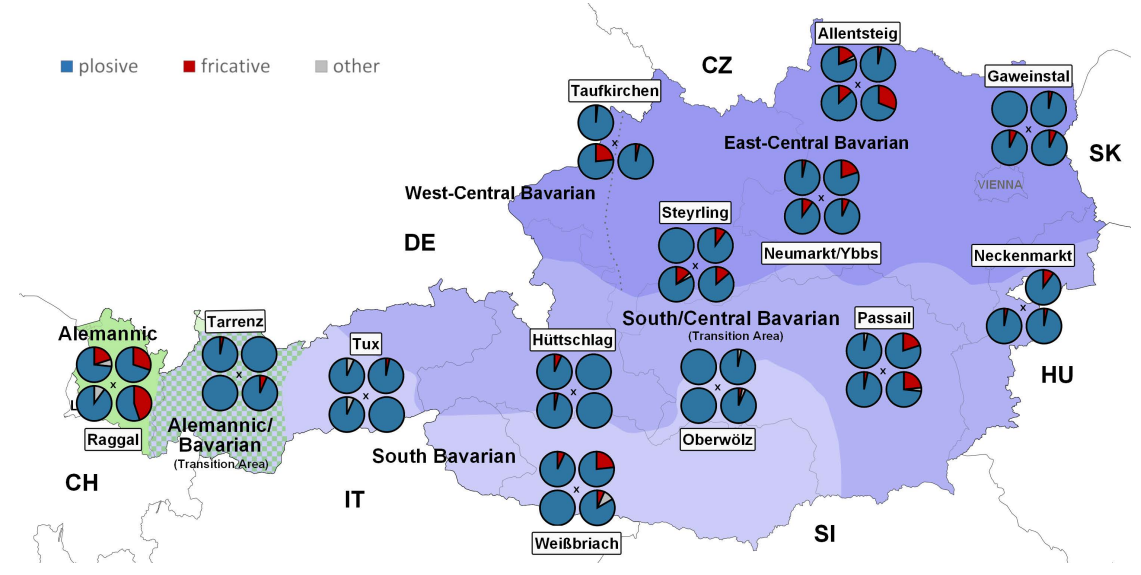

Fig. 9: 〈-ig〉-pronunciations by gender, generation and region $(n=1550$;

30 per speaker), all "standard intended settings" taken together.

The statistical analysis of the factors DIALECT REGION and GENDER show a significant effect regarding GENDER, in that female participants pronounce more fricatives than male participants $(\beta=1.173, \mathrm{SE}=0.452, \mathrm{Z}=2.597, \mathrm{p}=0.009)$ and that in contrast to Central Bavarian, in South Bavarian significantly fewer fricatives occur $(\beta=-1.684, \mathrm{SE}=0.640, \mathrm{Z}=-2.630, \mathrm{p}=0.009)$, while no statistical difference could be found for the South/Central Bavarian transition zone in comparison to Central Bavarian $(\beta=0.676, \mathrm{SE}=0.567, \mathrm{Z}=-1.193, \mathrm{p}=0.233)$. Interestingly, in Alemannic more fricatives occur than in Central Bavarian $(\beta=1.594$, SE $=0.774$, $\mathrm{Z}=2.059, \mathrm{p}=0.040$ ), but note that this is represented only by one location. In the Alemannic/Bavarian transition zone however, compared to Central Bavarian, a tendency towards fewer fricatives could be proven $(\beta=-1.886, \mathrm{SE}=0.999, \mathrm{Z}=-1.887$, $\mathrm{p}=0.059$ ). Interestingly, this regional variation corresponds with a relative distance from Innsbruck, which is the capital of Tyrol, and a little northwest of Tux in South Bavarian, indicating that the further away from Innsbruck the more fricatives occur $(\beta=1.877, \mathrm{SE}=0.913, \mathrm{Z}=2.056, \mathrm{p}=0.040)$.

\subsubsection{Dialect realizations of 〈-ig〉}

Since standard pronunciations could depend on the dialect background of the participants, Figure 10 shows the $<$-ig $>$-realizations of the dialect translation task. Unfortunately, only two items containing 〈-ig〉 occur in the "Wenker sentences" (artig 'well-behaved', fertig 'ready'), leading to merely 76 pronunciations in total. Consider that the word artig is frequently replaced by the heteronym brav, which could not be included in the analysis. Also, note that in Neckenmarkt and 
Taufkirchen two older participants of the same gender constitute the single pie charts, resulting in 4 instead of 2 analyzed words.

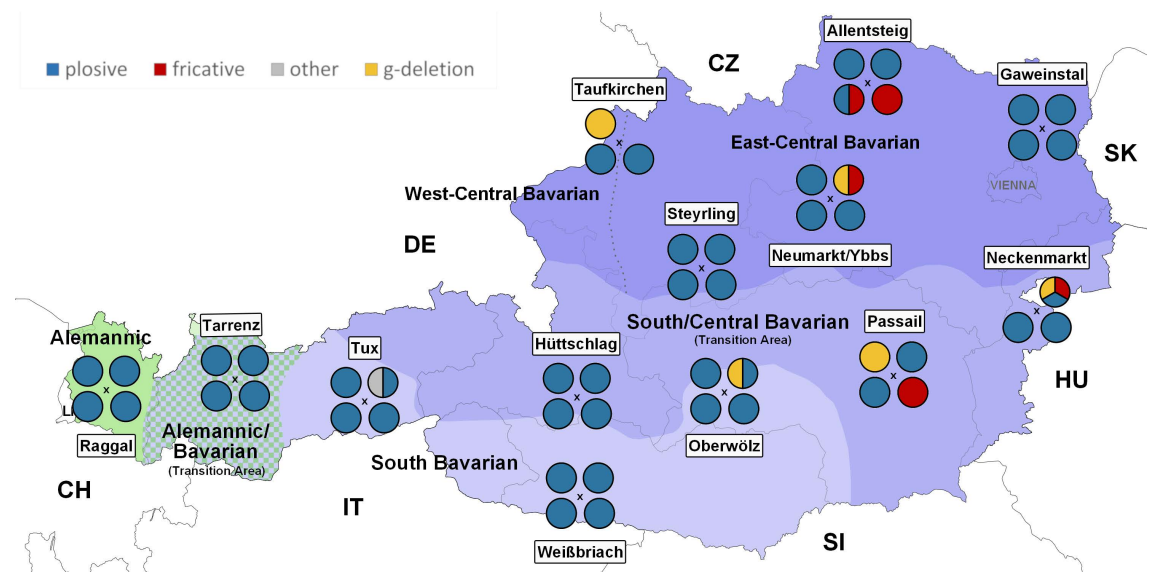

Fig. 10: Dialect 〈-ig〉-pronunciations by gender, generation and region ( $\mathrm{n}=76 ; 2$ per speaker), setting: translating "Wenker sentences" from standard German into local dialect.

Figure 10 shows that [iç] occurs in dialects of eastern Austria, mainly among female speakers. Surprisingly, it occurs primarily among young speakers, and only to a smaller degree among old participants in Neckenmarkt and Neumarkt/Ybbs. Based on the description of fricative pronunciation in dialects in the early 20th century by Luick (1996 [1904]), more fricatives among old participants, especially in the area of Vienna, would have been expected. However, $g$ deletion seems to be a legitimate form in a few locations, yet with no clear regional pattern. Further studies will be needed to describe the variation of 〈-ig〉 with regard to the complex Austrian dialect landscape.

\subsection{Discussion of the research results}

Summarizing all results, we identified a strong general preference (91\%) for plosive-usage among the 52 participants analyzed across Austria. This result corresponds with former studies (mostly limited to eastern Austria) demonstrating highly educated Austrian laypeople mostly using plosives. However, we attested even higher rates of plosives than Thévenanz (2018) with 76\% and Hildenbrandt $\&$ Moosmüller (2015) with $88.5 \%$. These (slight) differences between the amount of plosives may be due to the composition of the used stimuli, since the phonetic context in the respective lexemes as well as its part of speech influences the <-ig)pronunciation. One further reason for these differences may be the fact that our data include an older generation, which is absent in previous studies. It is possible that the older generation uses fewer fricatives than the young 'trendsetters', who 
have a stronger orientation towards the German German standard norm. However, surprisingly, we found no significant difference between the $\langle$-ig $>$-pronunciations of both generations and therefore, pace previous studies, this factor cannot be responsible for the enhanced plosive realizations. Our results furthermore support the assumption that (linguistically untrained) laypeople use far fewer fricatives than model speakers, since Thévenanz (2018) and Hildenbrandt \& Moosmüller (2015) determined Austrian newscasters' pronunciation of plosives and fricatives to be very balanced ( $56 \%$ or $53 \%$ plosives). Note, that Wonka (2015) found similar values for newscasters ( $76 \%$ plosives) as the above-mentioned studies for educated laypeople.

Nota bene: For most of our participants a strong inter-speaker variability was detected regarding the pronunciation of 〈-ig〉. This is exemplified in Figure 11, which represents the $\langle$-ig $\rangle$-realization in the context preceding the syllable -keit where most fricatives occur. The map is based on two records for each person. Excluding Tux (Tyrol, South Bavarian), a combination of plosives and fricatives can be attested for all locations. The realization of $\langle-\mathrm{ig}\rangle$ as fricative is used by at least one of the younger speakers in each location, the only exception is SouthCentral Bavarian Hüttschlag in the state of Salzburg. However, there are five locations with fricative realizations in which older participants articulate only plosives. Allthough we cannot distinguish any statistical age effects in our data, it seems that at least in this phonetic context a high tendency towards fricatives exists among the younger generation.

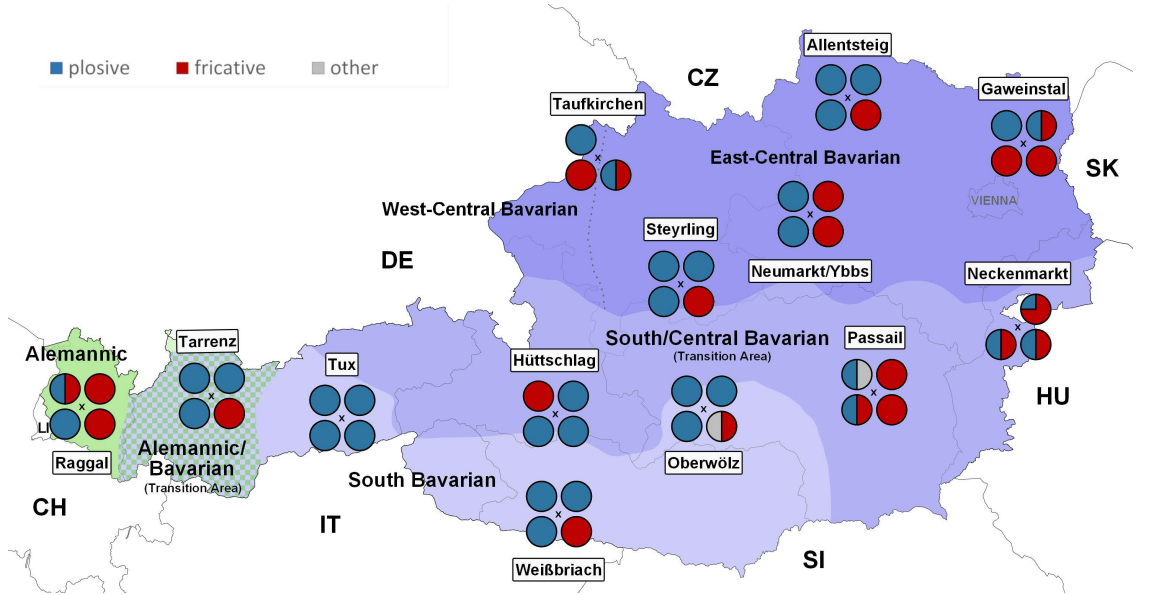

Fig. 11: 〈-ig〉-pronunciations by gender, generation and region before -keit $(n=104)$, setting: word list. 
A close scrutiny of the data reveals that different parameters play an important role for the variation of $\langle$-ig $\rangle$ : linguistic factors including phonetic context and part of speech, methodological factors considering situational effects (translation vs. reading tasks) or the way of presenting experimental stimuli (written vs. oral vs. pictured), as well as sociolinguistic factors such as gender or place of origin. Figure 12 displays an overview of the parameters, which are responsible for the most fricatives.

One main result of this study is that phonetic context and part of speech play a decisive role in explaining the $\langle$-ig $\rangle$-variation. In this context, most fricatives occur in derivations with -keit and in final position in cardinals. These results perfectly match previous studies. For example, Kleiner (2010) and Thévenanz (2018) find that in Austria <-ig> before /t/ and /s/ is mostly pronounced with plosive, while before -keit most fricatives occur. The predominance of fricatives before -keit is further supported by Bürkle (1995) and Hildenbrandt \& Moosmüller (2015). Ehrlich (2009) finds more fricatives in final position than before $/ \mathrm{s} /$ and /t/ as well, and Hildenbrandt \& Moosmüller (2015) underline the relatively high amount of fricatives $(20 \%)$ in final position in numerals. Fricatives in final position in cardinals come on second place. Our data match Thévenanz' (2018) tendencies in this regard, however, our data again provide fewer fricatives in these positions compared with other studies. For instance, Thévenanz (2018) found $80 \%$ fricatives before -keit, while in our data only $36.5 \%$ could be proven.

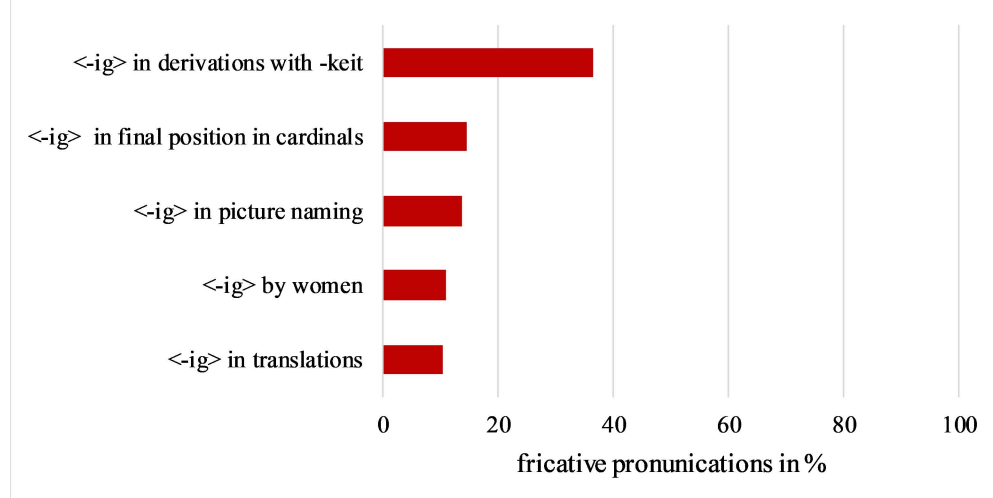

Fig. 12: Overview of the most relevant parameters influencing fricative pronunciation $(\mathrm{n}=1550)$, all "standard intended settings" taken together.

In any case, since the other studies on Austrian laypeople are based on different data, no one-to-one comparison is possible.

Considering the factors phonetic context and part of speech in order to compare model speakers and laypeople supports the idea that model speakers use even more 
fricatives in contexts where our data provide hardly any fricatives. For example, before $/ \mathrm{t} /$ and $/ \mathrm{s} /$ in superlatives as well as in final position in adjectives and substantives (see Hildenbrandt \& Moosmüller 2015, Thévenanz 2018). The second important linguistic factor, which is responsible for the $<$-ig $\rangle$-variation, is the methodology of data collection. We found significantly more fricatives in tasks without written stimuli like translations from dialect to standard and during picture naming. Therefore, we could identify a spelling pronunciation effect concerning <-ig〉. The graphic representation supports the Austrian [Ik]-variant leading to enhanced plosive realizations during reading. This effect is discussed by Kleiner (2010: 276), who explains the higher amount of cardinals, which were displayed as numbers in his study, in contrast to adjectives, which were written stimuli, using the spelling pronunciation effect. In our study, cardinals were presented in different settings, namely written or as numbers, and analyzed jointly with other pictures or written stimuli. Accordingly, comparing written cardinals with displayed numbers separately ( 44 vs. vierundvierzig 'forty-four' and 20 vs. zwanzig 'twenty'), more fricatives (12.5\%) occur in numbers in contrast to written stimuli (3.8\%). However, note that - as previously mentioned - cardinals are overrepresented in the non-written data, which influences the results for this setting.

Concerning sociolinguistic factors, we identified the most fricatives in women from Central Bavarian, including the South/Central Bavarian transition zone and Alemannic, while significantly fewer fricatives occur in the Alemannic/Bavarian transition zone and in South Bavarian. Thus, the results of Kleiner (2010: 273), who finds more fricatives in the eastern part of Austria than in the west are confirmed, excluding the Alemannic location Raggal. The data of Thévenanz (2018: 76-77) indicate a similar trend, namely less plosive <-ig >-realizations from speakers from Carinthia and Salzburg in contrast to Vienna, Lower Austria, Upper Austria and Styria.

To explain the regional variation of $\langle$-ig $\rangle$ it is also important to take the dialect background into account. Our dialect data show fricatives occurring in Central Bavarian and the South/Bavarian transition zone, and an absence of fricatives in Alemannic (see Figure 10). Thus, different norm orientations in both regions may be assumed. In Raggal, our data suggest a clear orientation towards the German German standard norm, clearly developing against the dialect. This may also be the case in eastern Austria, although a transfer from the local dialects seems plausible, indicating two competing norms. The plosive could be used as a marker of 'standardness' for some participants, while other speakers adopt the standard German German norms of 〈-ig)-articulation (see Hildenbrandt \& Moosmüller 2015: 125). However, even in Germany [Ik] occurs in "standard usage" and is perceived as being norm compliant by laypeople (see e.g., Kleiner 2010, Kehrein 2009, Kiesewalter 2014). Given the higher frequencies of fricatives among Austrian news broadcasters in previous studies (see e.g. Hildenbrandt \& Moosmüller 
2015: 118-125) and the general tendency of mainly young woman (age was not statistically significant though) using [Iç] to a great extent, further diffusion of this variant can be predicted in the future. This depends, of course, on the plosive being equipped with a new sociosymbolic function and reaching a status of marking regional or national identity.

\section{Résumé}

The focus of the present contribution is on Austrian standard German in the context of transnationally diverging pronunciation norms and "standard usage". The discussion concentrates on Austria and thus, from a "pluricentric" point of view, a non-dominant centre of German, which is strongly linguistically influenced by Germany. In Austria, codified pronunciation rules, and thus accepted norms for an Austrian standard, are disputed. Although there are some attempts to describe an Austrian standard, no prescribed and nation-wide accepted pronunciation norm has been established yet. Austrian laypeople are exposed to the German German standard via German television, international film dubbing and to some form of Austrian standard by Austrian model speakers in television and radio. Although German pronunciation dictionaries (more descriptively than prescriptively) meanwhile mention Austrian characteristics (often as "deviations" from the "actual" standard), and single empirical studies examine the pronunciation of (trained) model speakers (e.g., newscasters) and (rather untrained and young) academics, there is still a lack of comparative and nation-wide studies focusing on the standard language use in Austria of laypeople from different generations.

This paper closes this research gap by exploring the realization of unstressed 〈-ig〉 in survey settings where standard language was explicitly requested. The choice of unstressed <-ig〉 as the subject of interest is due to the fact that its pronunciation has been considered controversial since the beginnings of pronunciation standardization, more than 120 years ago. In contrast to other contexts of (g)spelling in German, unstressed <-ig〉 is the only context, in which codices predominantly recommend pronunciation as a fricative - at least for the German German standard. Contrarily, pronunciation dictionaries stipulate the plosive variant for Austria, which is said to be the predominant variant used by Austrian speakers.

In addition to international and interregional differences, concerning pronunciation norms and "standard usage" patterns, the $\langle-\mathrm{ig}\rangle$-variation is subjected to complex linguistic control factors, which were also considered in our study. Our database includes speech material from 52 speakers from two generations (1835 and 65+) from 13 villages spread over all major dialect areas in Austria. Each participant was required to perform four survey tasks: reading a text, reading a 
word list, naming pictures and translating dialect into standard German. The results considered linguistic and sociolinguistic factors, showing that $\langle-\mathrm{ig}\rangle$ mostly is pronounced as a plosive, while fricatives predominantly occur preceding -keit and in cardinals. Interestingly, the context preceding -keit is an exceptional position regarding fricative frequencies in Germany and Switzerland as well. Furthermore, a spelling pronunciation effect was detected, since during reading, more plosive variants occured than during picture naming or translations. In addition, we identified the highest amounts of fricatives among women (especially from eastern Austria and the Alemannic west). In contrast, males from South Bavarian in particular show strong loyalty towards the $\langle$-ig $\rangle$-pronunciation as plosive.

In total, the "standard" pronunciation of <-ig〉 is a complex linguistic and sociolinguistic phenomenon of German, especially in Austria. Concerning norms, the plosive is recommended for Austria (Austrian perspective) or rather tolerated (German German perspective). Following Ammon (1995) and his "field of social forces of a standard variety" a variant reaches the status of standard when it occurs with a certain frequency in model texts, when it is judged as being standard by language experts, and when it is codified by pronunciation dictionaries (see Ammon et al. 2016: XIII). All these factors apply for the plosive <-ig〉-realization leading to an acceptance of [ $\mathrm{ik}]$ as an Austrian standard.

However, previous studies indicate that - depending on complex linguistic and sociolinguistic factors - fricatives also occur in standard contexts. Model speakers (newsreaders) tend to deviate from the "plosive pronunciation norm". Therefore, German speaking Austrians are situated in a conflict between transnationally diverging norms and intra-nationally varying model speakers of German. Interestingly, our data demonstrate that women, in particular, show a stronger preference for fricatives in comparison to their male counterparts of the same location. The usage of fricatives among model speakers as well as female speakers could be interpreted as indicators of a slight convergence to the German German norm.

Funding: The research presented here is supported by the Austrian Science Foundation within the framework of the Special Research Programme "German in Austria. Variation - Contact - Perception" (FWF F60-G23), Project Part "Between dialects and standard varieties: Speech repertoires and varietal spectra" (FWF F06003, principal investigator: Alexandra N. Lenz).

Acknowledgements: The authors thank Joachim Herrgen, Roland Kehrein, Stefan Kleiner, and Henry Widdowson for their helpful feedback, Barbara Binder, and Florian Tavernier for their help in phonetic transcriptions as well as all participants of the survey. 


\section{References}

Ammon, Ulrich. 1995. Die deutsche Sprache in Deutschland, Österreich und der Schweiz: Das Problem der nationalen Varietäten. Berlin/New York: de Gruyter.

Ammon, Ulrich. 2005. Standard und Variation: Norm, Autorität, Legitimation. In Standardvariation: Wie viel Variation verträgt die deutsche Sprache? (Jahrbuch des Instituts für Deutsche Sprache 2004), 28-40, eds. Ludwig M. Eichinger \& Werner Kallmeyer. Berlin/New York: de Gruyter.

Ammon, Ulrich, Hans Bickel \& Alexandra N. Lenz. 2016. Variantenwörterbuch des Deutschen: Die Standardsprache in Österreich, der Schweiz, Deutschland, Liechtenstein, Luxemburg, Ostbelgien und Südtirol sowie Rumänien, Namibia und Mennonitensiedlungen. Berlin/Boston: de Gruyter.

Auer, Peter. 2013. Enregistering pluricentric German. In Pluricentricity: Language variation and sociocognitive dimensions, 19-48, ed. Augusto S. da Silva. Berlin/ Boston: De Gruyter Mouton.

Bates, Douglas, Martin Maechler, Ben Bolker \& Steve Walker. 2015. Fitting linear mixed-effect models using lme4. Journal of Statistical Software 67: 1-48.

Bickel, Hans \& Christoph Landolt. 2012. Duden Schweizerhochdeutsch: Wörterbuch der Standardsprache in der deutschen Schweiz. Hrsg. vom Schweizerischen Verein für die deutsche Sprache. Mannheim/Zürich: Duden.

Budin, Gerhard, Stephan Elspaß, Alexandra N. Lenz, Stefan M. Newerkla \& Arne Ziegler. 2019. The Research Project (SFB) 'German in Austria': Variation - Contact - Perception. In Dimensionen des sprachlichen Raums: Variation - Mehrsprachigkeit-Konzeptualisierung (Schriften zur deutschen Sprache in Österreich 45), 7-35, eds. Lars Bülow, Ann K. Fischer \& Kristina Herbert. Frankfurt am Main: Peter Lang.

Budin, Gerhard, Stephan Elspaß, Alexandra N. Lenz, Stefan M. Newerkla \& Arne Ziegler. 201. Der Spezialforschungsbereich „Deutsch in Österreich (DiÖ). Variation Kontakt - Perzeption": The Special Research Programme "German in Austria (DiÖ). Variation - Contact - Perception". Zeitschrift für germanistische Linguistik. Deutsche Sprache in Gegenwart und Geschichte 46: 300-308.

Bürkle, Michael. 1995. Zur Aussprache des österreichischen Standarddeutschen:Die unbetonten Silben (Schriften zur deutschen Sprache in Österreich 17). Frankfurt am Main u.a.: Peter Lang.

Chambers, Jack \& Peter Trudgill. 1993. Dialectology, 2. Edition. Cambridge/New York: Cambridge University Press.

Clyne, Michael. 1992. Pluricentric languages - Introduction. In Pluricentric languages (Contributions to the Sociology of Language 62), 1-9, ed. Michael Clyne. Berlin/New York: Mouton de Gruyter.

Clyne, Michael. 1995. The German language in a changing Europe. Cambridge: Cambridge University Press.

Deppermann, Arnulf, Stefan Kleiner \& Ralf Knöbel. 2013. 'Standard usage': Towards a realistic conception of spoken standard German. In Language Variation 
- European Perspectives IV: Selected papers from the Sixth International Conference on Language Variation in Europe (ICLaVE 6), Freiburg, June 2011 (Studies in Language Variation 14), 83-116, eds. Göz Kaufmann, Javier C. Reina $\&$ Peter Auer. Amsterdam/Philadelphia: John Benjamins.

Duden. 2015. Das Aussprachebuch: Aussprache und Betonung von über 132.000 Wörtern und Namen. Bearb. von Stefan Kleiner \& Ralf Knöbl. 7., komplett überarb. und aktual. Auflage (Duden 6). Berlin: Duden.

Ehrlich, Karoline. 2009. Die Aussprache des österreichischen Standarddeutsch-umfassende Sprech und Sprachstandserhebung der österreichischen Orthoepie. Wien: Universität Wien Inaugural-Dissertation.

Elspaß, Stephan \& Robert Möller. 2003ff. Altas zur deutschen Allagssprache. http://www.atlas-alltagssprache.de/ (acc. 17 June 2019).

Ganswindt, Brigitte, Roland Kehrein \& Alfred Lameli. 2015. Regionalsprache.de (REDE). In Regionale Variation im Deutschen: Projekte und Perspektiven, 425457, eds. Roland Kehrein, Alfred Lameli \& Stefan Rabanus. Berlin/Boston: De Gruyter Mouton.

Glauninger, Manfred M. 2013. Deutsch im 21. Jahrhundert: „pluri“-, „,supra“- oder „postnational“? In Mitteleuropa. Kontakte und Kontroversen: II. Kongress des Mitteleuropäischen Germanistenverbandes (MGV) in Olmütz, 13.-16. September 2007 (Veröffentlichungen des Mitteleuropäischen Germanistenverbandes 2), 459-468, eds. Ingborn Fiala-Fürst, Jürgen Joachimsthaler \& Walter Schmitz. Dresden: Thelem.

Herrgen, Joachim. 2015. Entnationalisierung des Standards: Eine perzeptionslinguistische Untersuchung zur deutschen Standardsprache in Deutschland, Österreich und der Schweiz. In Standarddeutsch im 21. Jahrhundert: Theoretische und empirische Ansätze mit einem Fokus aufÖsterreich (Wiener Arbeiten zur Linguistik 1), 139-164, eds. Alexandra N. Lenz \& Manfred M. Glauninger. Wien: Vienna University Press.

Hildenbrandt, Tina \& Sylvia Moosmüller. 2015. The pronunciation of -ig in three varieties of Austria. In Language variation - European perspectives V: Selected papers from the seventh International Conference on Language Variation in Europe (ICLaVE 7), Trondheim, June 2013 (Studies in Language Variation 17), 111-128, eds. Eivind Torgersen, Stian Hårstad, Brit Mæhlum \& Unn Røyneland. Amsterdam/Philadelphia: John Benjamins.

Hirschfeld, Ursula. 2009. Rezension zu: Rudolf Muhr (2007): Österreichisches Aussprachewörterbuch. Österreischische Aussprachedatenbank. Frankfurt am Main u.a.: Peter Lang. In Theorie und Praxis. Österreichische Beiträge zu Deutsch als Fremdsprache. Serie A: 12/2008. Schwerpunkt: Sprache und Integration, 205212, eds. Hans-Jürgen Krumm \& Paul R. Portmann-Tselikas. Innsbruck/Wien/ Bozen: Studienverlag.

Kehrein, Roland. 2009. Dialektalität von Vorleseaussprache im diatopischen Vergleich - Hörerurteil und phonetische Messung. Zeitschrift für Dialektologie und Linguistik 76: 14-54. 
Kiesewalter, Carolin. 2014. Salienz und Pertinzenz: Zur subjektiven Dialektalität remanenter Regionalismen des Mittelbairischen. Linguistik online 66: 111-134.

Klein, Wolf P. 2013. Warum brauchen wir einen klaren Begriff von Standardsprachlichkeit und wie könnte er gefasst werden? In Pragmatischer Standard, 15-33, eds. Jörg Hagemann, Wolf P. Klein \& Sven Staffeldt. Tübingen: Staffenburg.

Kleiner, Stefan. 2011ff. Atlas zur Aussprache des deutschen Gebrauchsstandard (AADG): Unter Mitarbeit von Ralf Knöbl.

http://prowiki.ids-mannheim.de/bin/view/AADG/ (acc. 17 June 2019)

Kleiner, Stefan. 2008. Rezension zu: Muhr, Rudolf (2007): Österreichisches Aussprachewörterbuch. Österreischische Aussprachedatenbank. Frankfurt am Main u.a.: Peter Lang. Zeitschrift für Dialektologie und Linguistik 75: 369-737.

Kleiner, Stefan. 2010. Zur Aussprache von nebentonigem -ig im deutschen Gebrauchsstandard. Zeitschrift für Dialektologie und Linguistik 77: 259-303.

Kleiner, Stefan. 2014. Die Kodifizierung der deutschen Standardaussprache im Spiegel der faktischen Variabilität des Gebrauchsstandards. In Sprachverfall? Dynamik - Wandel - Variation (Jahrbuch des Instituts für Deutsche Sprache. 2013), 273-298, eds. Albrecht Plewina \& Andreas Witt. Berlin/Boston: de Gruyter.

Kleiner, Stefan, Nina Berend, Caren Brinckmann \& Ralf Knöbel. 2011. „Deutsch heute": Ein sprachgebietsweites Forschungsprojekt zur regionalen Variation in der gesprochenen deutschen Standardsprache. In Akten der 10. Arbeitstagung für bayerisch-österreichische Dialektologie in Klagenfurt 2007 (Klagenfurter Beiträge zur Sprachwissenschaft 34-36), 179-193, ed. Heinz-Dieter Pohl. Wien: Praesens.

König, Werner. 1989a. Atlas zur Aussprache des Schriftdeutschen in der Bundesrepublik Deutschland. Band I: Text. Ismaning: Max Hueber.

König, Werner. 1989b. Atlas zur Aussprache des Schriftdeutschen in der Bundesrepublik Deutschland. Band II: Tabellen und Karten. Ismaning: Max Hueber.

König, Werner. 2008. Spricht man in Norddeutschland ein besseres Hochdeutsch? Waseda-Blätter 15: 45-64.

Kranzmayer, Eberhard. 1956. Historische Lautgeographie des gesamtbairischen Dialektraumes: mit 27 Laut- und 4 Hilfskarten in besonderer Mappe. Wien: Druck von Ferdinand Berger in Horn.

Krech, Eva-Maria, Eberhard Stock, Ursula Hirschfeld \& Lutz C. Anders (eds.). 2009. Deutsches Aussprachewörterbuch: Mit Beiträgen von Walter Haas, Ingrid Hove und Peter Wiesinger. Berlin/New York: de Gruyter.

Lameli, Alfred. 2004. Standard und Substandard: Regionalismen im diachronen Längsschnitt (Zeitschrift für Dialektologie und Linguistik. Beihefte 128). Stuttgart: Steiner.

Lenz, Alexandra N. 2010. Emergence of varieties through restructuring and reevaluation. In Language and space. An international handbook of linguistic variation. Vol. 1: Theories and methods (Handbücher zur Sprach- und Kommunikationswissenschaft 30.1), 295-315, eds. Peter Auer, Jürgen E. Schmidt. Berlin/New York: De Gruyter Mouton. 
Lenz, Alexandra N. 2018. The Special Research Programme "German in Austria. Variation - Contact - Perception. In Sprachwahl im Tourismus - mit Schwerpunkt Europa.: Language Choice in Tourism - focus on Europe. Choix de langues dans le tourisme - focus sur l'Europe. (Yearbook Sociolinguistica 32), 269-277, eds. Ulrich Ammon \& Marcella Costa. Berlin/Boston: de Gruyter.

Luick, Karl. 1996 [1904]. Deutsche Lautlehre: Mit besonderer Berücksichtigung der Sprechweise Wiens und der österreichischen Alpenländer. Nebst einem Nachdruck des ,,Österreichischen Beiblattes zu Siebs “. Hrsg. von Otto Back. Repr. der dritten Auflage von 1932. Wien: ÖBV Pädagogischer Verlag.

Maitz, Péter \& Stephan Elspaß. 2013. Zur Ideologie des ,Gesprochenen Standarddeutsch'. In Pragmatischer Standard, 35-48, eds. Jörg Hagemann, Wolf P. Klein $\&$ Sven Staffeldt. Tübingen: Staffenburg.

Moosmüller, Sylvia, Carolin Schmid \& Julia Brandstätter. 2015. Standard Austrian German. Journal of the International Phonetic Association 45: 339-348.

Muhr, Rudolf. 2007. Österreichisches Aussprachewörterbuch. Österreichische Aussprachedatenbank. Frankfurt am Main u.a.: Peter Lang.

ÖWB. 2016. Österreichisches Wörterbuch: Herausgegeben im Auftrag des Bundesministeriums für Bildung, 43., aktual. Auflage. Wien: ÖBV.

R Core Team. 2018. R: A language and environment for statistical computing: R Foundation for Statistical Computing.

Scheuringer, Hermann. 1996. Das Deutsche als pluriareale Sprache: Ein Beitrag gegen staatlich begrenzte Horizonte in der Diskussion um die deutsche Sprache in Österreich. Die Unterrichtspraxis / Teaching German 29: 147-153.

Schmidlin, Regula. 2011. Die Vielfalt des Deutschen: Standard und Variation: Gebrauch, Einschätzung und Kodifizierung einer plurizentrischen Sprache. Berlin/Boston: de Gruyter.

Schmidt, Jürgen E. \& Joachim Herrgen. 2011. Sprachdynamik: Eine Einführung in die moderne Regionalsprachenforschung (Grundlagen der Germanistik 49). Berlin: Erich Schmidt Verlag.

Siebs. 1969. Deutsche Aussprache: Reine und gemäßigte Hochlautung mit Aussprachewörterbuch. Hrsg. von Helmut de Boor, Hugo Moser \& Christian Winkler. 19., umgearb. Auflage. Berlin: Walter de Gruyter.

Siebs, Theodor. 1898. Deutsche Bühnenaussprache: Ergebnisse der Beratungen zur ausgleichenden Regelung der deutschen Bühnenaussprache, die vom 14. bis 16. April 1898 im Apollosaale des königlichen Schauspielhauses zu Berlin stattgefunden haben. Berlin/Köln/Leipzig: Albert Ahn.

Takahashi, Hideali. 1996. Die richtige Aussprache ds Deutschen in Deutschland, Österreich und der Schweiz nach Maßgabe der kodifizierten Normen (Duisburger Arbeiten zur Sprach- und Kulturwissenschaft 27). Frankfurt am Main: Peter Lang.

Thévenanz, Clara. 2018. Standardsprechsprache im Spannungsfeld zwischen Norm und Variation - Nebentoniges -ig in Österreich. Wien: Universität Wien Masterarbeit. 
Wiesinger, Peter. 2009a. Die Standardaussprache in Österreich. In Deutsches Aussprachewörterbuch: Mit Beiträgen von Walter Haas, Ingrid Hove und Peter Wiesinger, 229-258, eds. Eva-Maria Krech, Eberhard Stock, Ursula Hirschfeld \& Lutz C. Anders. Berlin/New York: de Gruyter.

Wiesinger, Peter. 2009b. Rezension zu: Muhr, Rudolf (2007): Österreichisches Aussprachewörterbuch. Österreichische Aussprachedatenbank. Frankfurt am Main u.a.: Peter Lang. Beiträge zur Namenforschung 44: 243-250.

Wonka, Lisa. 2015. Merkmale des gesprochenen österreichischen Deutsch anhand einer Analyse von ORF-Sendungen. Wien: Praesens.

Manuela Lanwermeyer·Manuela.Lanwermeyer@univie.ac.at Johanna Fanta-Jende·Johanna.Fanta@univie.ac.at Alexandra N. Lenz·Alexandra.Lenz@univie.ac.at Katharina Korecky-Kröll · Katharina.Korecky-Kroell@univie.ac.at Department of German Studies · University of Vienna · AUSTRIA 